\title{
EVALUATION OF GROWTH AND FLOWERING OF CULTIVARS DERIVED FROM THE RUGOSA (Rosa rugosa Thunb.) GROWING IN THE NATIONAL COLLECTION OF ROSE CULTIVARS IN THE POLISH ACADEMY OF SCIENCES BOTANICAL GARDEN IN POWSIN

\author{
PART I. THE HISTORICAL CULTIVARS
}

\author{
Marta Joanna Monder \\ Polish Academy of Sciences Botanical Garden - Center for Biological Diversity Conservation in Powsin, \\ Department of Botanical and Horticultural Collections, Prawdziwka 2, 02-973 Warsaw, Poland, \\ e-mail: mondermarta@obpan.pl
}

Received: 05.12.2011

\begin{abstract}
In the years 2000-2011, observations were made of shrubs of the cultivars derived from the Rugosa ( $R$. rugosa Thunb.) gathered in the Collection of Rose Cultivars of the Polish Academy of Sciences (PAS) Botanical Garden - Center for Biological Diversity Conservation (CBDC) in Powsin, Poland, including 29 cultivars. In the first part, the results are presented for 12 historical cultivars ('Agnes', 'Belle Poitevine', 'Blanc Double de Coubert', 'F.J. Grootendorst', 'Frau Dagmar Hastrup', 'Hansa', 'Kaiserin des Nordens', 'Max Graf', 'Moje Hammarberg', 'Mrs Anthony Waterer', 'Pink Grootendorst', 'Rugeaux du Japon').

Every year, damage to shrubs caused by frost was recorded; the date of bud break and the date when leaves developed in springtime were recorded; regeneration of shrubs damaged in winter was observed; the dates of initial, full and final flowering were recorded; the presence of disease symptoms was observed; and notes were made concerning the need to do spring pruning and pruning after flowering. The winter seasons 2002/2003, 2005/2006, 2009/2010, 2010/2011 were unfavourable for roses. In terms of the features in question, the cultivars varied. The cultivars derived from the Rugosa should find a wider application as park roses ('Agnes', 'Belle Poitevine', 'F.J. Grootendorst', 'Frau Dagmar Hastrup', 'Mrs Anthony Waterer', 'Pink Grootendorst', 'Rugeaux du Japon') as well as ground cover and soil protection roses ('Blanc Double de Coubert', 'Hansa', 'Kaiserin des Nordens', 'Max Graf', 'Moje Hammarberg') planted in urban green areas and near historical buildings.
\end{abstract}

Key words: Botanical Garden, Rosa rugosa, shrub roses, ground cover roses, frost damage, greenery, hedge, collection

\section{INTRODUCTION}

In the years 1998-2011, the Collection of Rose Cultivars in the Polish Academy of Sciences (PAS) Botanical Garden in Powsin gathered more than 700 species and varieties of roses, out of which 35 are Rugosa hybrids.

The Rugosa (Rosa rugosa Thunb.) belongs to the species-richest subgenus Rosa (Eurosa) in the section Cinnamomeae DC (P o p e k, 1996). It comes from the seashores of the Far East (Korean Peninsula to Sakhalin) and occurs in the natural environment in Poland as an alien species (B u g a ł a , 2000). The Rugosa was brought to Europe around 1796 (K r ü s s m a n n, 1974). Shrubs of Rosa rugosa Thunb. can withstand frost of up to $-35^{\circ} \mathrm{C}$ (J e r z y et al. 1992) in 2 planting zones (Heinze et al. 1984) and are highly resistant to air pollution, drought, poor soils, salinity as well as salt sprinkled on roads (P o pe k, 2002). For those reasons, it is recommended for locations which are not very favourable for the growth of plants, e.g. along transport routes, on slopes, mounds, dunes, which it additionally strengthens by expanding through suckers. In addition, its significant value in ecosystems was proven ( $\mathrm{Szkl}$ an ow ska, 1992; P ope k, 2002). However, the Rugosa was found to be an increasingly numerous invasive species, which should be controlled in Poland. It is recommended not to be cultivated in protected areas and their buffer zones (www.iop.krakow.pl). 
Breeders became interested in it late, that is, as late as at the end of the 19th century, and this resulted in obtaining numerous cultivars by crossing the Rugosa with representatives of other rose groups. Since then, the Rugosa has had an important share in breeding park and climbing roses (e.g. Rosa xkordesii Wulff.) (A nd e r s on, 1932; K r ü s s m a n n, 1974) which are highly resistant to frost and diseases; these are usually repeat-flowering roses (C a r l s o n, 1993; O gilvie and Arnold, 1995), fruit roses (K r ü s s $m$ a $n ~ n, 1974$ ) and, since the end of the 20th century, also ground cover roses (M o n d e r , 2001).

For many years now, in Poland there has been a tendency to establish interesting green areas, rich in species and cultivars, and at the same time increasing attention is being paid to how resistant plants are to diseases and frost and how easy they are to cultivate (Z a r a ś and L a t o c h a, 2000). Rugosa hybrids have wide applications, and historical cultivars give man-made landscapes a specific character, which is desirable especially when it comes to historic man-made landscapes. The condition of Polish historic gardens is bad and there are many reasons for this situation. Each park requires an individual approach. This subject-matter is widely discussed in research papers and renewal projects (Sik or a, 2006). Therefore, it is a good idea to become familiar with more valuable historical rose cultivars and resume their cultivation.

In the PAS Botanical Garden, growth and flowering of the cultivars derived from the Rugosa was observed since they had been planted. The aim of the research was to get to know better their cultivation and ornamental value and possible uses. This paper is divided into two parts. Part I of the paper presents the results obtained for twelve historical cultivars; for three other ones ('Mrs. Anthony Waterer', 'Rugeaux du Japon', 'F.J. Grootendorst'), partial results were presented earlier (M o n d e r, 2004b, 2007a, 2007b). The results obtained for modern cultivars are described in Part II of the paper (M o n d e r , 2012).

\section{MATERIALS}

The two parts of the paper present the results obtained for 29 cultivars derived from the Rugosa $(R$. rugosa L.) gathered in the Collection of Rose Cultivars of the PAS Botanical Garden - CBDC in Powsin, growing on their own roots or bud-grafted onto a rootstock (Rosa canina L. types; 'F.J. Grootendorst', 'Pink Grootendorst', 'Max Graf'). The cultivars were obtained mostly from Polish arborists and, to a small extent, from botanical gardens abroad. The shrubs were planted in the years 1998-2006. In the first part of the paper, the historical cultivars are presented, bred before the end of World War 2, while the second part presents the cultivars bred after World War 2. The twelve historical cultivars described in Part 1 are presented below, whereas the number and age of the shrubs as well as their origins are presented in Table 1.

Cultivars derived from the Rugosa can be divided into two subgroups: with the growth character, foliage and thorniness resembling the Rugosa and the other subgroup that is less similar to the species in terms of the external features mentioned ( $\mathrm{Kr} \ddot{\mathrm{u} s ~ s} \mathrm{mann}$, 1974; M o n d e r , 2001, 2009). Most of them have been described by A nders on (1932). The first subgroup includes: 'Belle Poitevine', 'Blanc Double de Coubert', 'Frau Dagmar Hastrup', 'Hansa', 'Moje Hammarberg', while the cultivars from the other subgroup are as follows: 'Agnes', 'F.J. Grootendorst', 'Kaiserin des Nordens', 'Max Graf', 'Mrs Anthony Waterer', 'Pink Grootendorst', 'Rugeaux du Japon' (Table 1).

\section{METHODS}

The observations were made on shrubs growing in the Collection of Rose Cultivars of the PAS Botanical Garden CBDC in Warsaw in the years 2000-2011. Each research object was represented by 2-10 shrubs. The shrubs were planted in a space which provided them with appropriate growth conditions. During the growing period of the shrubs, agrotechnical procedures were carried out according to the current technology of shrub cultivation in soil. The shrubs were not covered (hilled up) for winter, but flower beds were mulched with leaves or bark (a layer of 7-10 cm) every 2-3 years. During the season, on average 2-3 protective sprayings of plants against pests and fungal diseases are carried out in the collection.

Every spring, damage caused by frost was recorded according to the scale put forward by $€ \mathrm{uk}$ a s i e w i c z (1992) for non-evergreen plants (excluding points 2, 8, 9, as they are not applicable to roses). These are:

0 - undamaged plants;

1 - darkened vascular bundles on shoots, but buds develop;

2 - frost-damaged flower buds;

3 - frost-damaged leaf buds;

4 - frost-damaged one-year-old shoot tips;

5 - frost-damaged one-year-old shoots or only their living bases;

6 - frost-damaged also 2-year-old and older shoots;

7 - shoots frost-damaged to the ground surface (snow), but new shoots grow from the undamaged parts (shoot bases or roots);

8 - cracked shoots;

9 - damping off of the stem or boughs;

10 - complete plant frost damage (no signs of regeneration). 
The date of the development of buds on unpruned shoots was evaluated every spring, with the following division adopted:

E - early - buds usually develop in the second decade of March;

$\mathrm{S}$ - semi-early - buds usually develop in the third decade - the first week of April;

L - late - buds usually develop in the second week of April.

The date of the development of leaves on shoots was recorded every spring, with the periods divided as follows:

E - early - leaves usually develop 1-7.04;

S - semi-early - leaves usually develop 8-20.04;

$\mathrm{L}$ - late - leaves usually develop 21-31.04.

In addition, the average flowering time for the shrubs (dates of the initial, full and final flowering) as well as the height of the shrubs during the flowering period (the turn of May and June) and at the end of the growing season (at the end of October) were recorded. The condition of foliage was observed and notes were made concerning the need to do spring pruning and pruning after flowering.

\section{Weather conditions}

In the years 1999-2011, exceptionally unfavourable weather conditions occurred four times in the autumn-winter period: 2002/2003, 2005/2006, 2009/2010, 2010/2011. In those periods, the coldest months were January and February, and the lowest temperatures within $24 \mathrm{~h}$ periods were then recorded - below $-20^{\circ} \mathrm{C}$. During each of those winters, heavy snowfalls were recorded, with the heaviest one in the season 2009/2010. Average monthly temperatures in the period from October to April in the above-mentioned years and total annual precipitation in the years 1999-2011, based on the measurements carried out in the PAS Botanical Garden CBDC, are presented in Charts 1 and 2.

\section{RESULTS AND DISCUSSION}

The historical cultivars derived from the Rugosa vary in terms of their morphological features, cultivation requirements and resistance to frost, which is confirmed by the present observations, carried out for several years, with respect to the range being examined (Tables 2 and 3).

Most of the examined historical Rugosa cultivars winter well in the conditions of the Botanical Garden, even during severe winters. Among the studied cultivars, the shrubs of 'Agnes', 'F.J. Grootendorst', 'Max Graf', 'Mrs Anthony Waterer' and 'Pink Grootendorst', became slightly frost-damaged in unfavourable winter conditions (2002/2003, 2005/2006, 2009/2010, 2010/2011). Back then, little damage was recorded in the form of darkened vascular bundles and more rarely frost-damaged one-year-old shoots, very rarely older ones (Table 2). Such shrubs required light pruning, by approx. $1 / 3$ to $2 / 3$ of the height or length of shoots. They compensated for the loss quickly, obtaining the size proper for them by the autumn (Table 3).

In spring, early development of buds was observed in the shrubs of most cultivars of the Rugosa, beginning already from the last decade of March, as well as the development of leaves which often occurred already in the first decade of April. Most shrubs of the examined cultivars did not become frost-damaged, so they did not require pruning in spring, and therefore pruning did not delay their development, like with ground cover roses in Henschke's research (2007). Necessary rejuvenating pruning is carried out in the collection every couple of years in early spring by entirely cutting out the oldest shoots, so it does not affect their further vegetative development. In the case of the shrubs of the cultivars that had to be pruned in spring due to frost damage ('Agnes', 'F.J. Grootendorst', 'Pink Grootendorst', 'Max Graf' and 'Mrs Anthony Waterer'), buds and leaves began to develop a few days later than usually in relation to other years. The period of bud and leaf development was similar to many Pimpinellifolias, most of which also do not become frost-damaged in winter and do not require spring pruning (M o n d e r , 2011). The earliest development of buds and leaves was recorded for the following cultivars: 'Agnes', 'F.J. Grootendorst', 'Hansa', 'Pink Grootendorst', 'Rugeaux du Japon'. Buds in 'Dagmar Hastrup' and 'Max Graf' developed slightly later (Table 3).

The shrubs of the examined cultivars reached their specific height 2-4 years after they had been planted, and they maintained it for the whole study period. The highest shrubs are produced by 'F.J. Grootendorst', 'Hansa', 'Mrs Anthony Waterer', while the lowest ones by 'Frau Dagmar Hastrup' (Table 3). Not all cultivars spread by means of suckers equally intensely. 'Agnes' shrubs produced few suckers, whereas 'Mrs Anthony Waterer' and 'Max Graf' did not produce them at all. What is quite important is the soil-protective activity of roses producing suckers ( $\mathrm{P}$ o p e k, 2002): 'Blanc Double de Coubert', 'Frau Dagmar Hastrup', 'Hansa', 'Kaiserin des Nordens', 'Max Graf', 'Moje Hammarberg', 'Rugeaux du Japon'. A compact and quite regular habit occurs in 'F.J. Grootendorst' and 'Pink Grootendorst', which also produce few suckers and stand out among the researched cultivars as they can be planted for unclipped hedges.

Flowering with the examined cultivars begins early in comparison with numerous other cultivars from other groups (M o n d e r , 2004a, 2008a, 2008b, 2010) and similarly to Pimpinellifolias (M on de r, 2011) as well as many other historical roses (Monder, 
2007a). Shrubs flower from the second decade of May, the earliest in case of: 'Belle Poitevine', 'Frau Dagmar Hastrup', 'Kaiserin des Nordes', 'Moje Hammarberg'. The main flowering period lasts 3-4 weeks, ending in the second half of June when the cultivars from the group of ground cover roses begin to flower (M o n d e r, 2007b). 'Max Graf' and 'Mrs Anthony Waterer', as they flower on last year's shoots, flowered more poorly after frost damage. Flowering is repeated well by 'F.J. Grootendorst' and 'Pink Grootendorst', slightly more weakly by 'Moje Hammarberg'. Few flowers appeared in the remaining cultivars which repeat flowering. After flowering cessation, inflorescences were not removed. For aesthetic reasons, the procedure can be possibly carried out in some humid and cool summers with full-blossomed cultivars and cultivars which do not produce hips.

An additional ornamental element is that leaves turn yellow in autumn in the case of 'Belle Poitevine', 'Blanc Double de Coubert', 'F.J. Grootendorst', 'Frau Dagmar Hastrup', 'Hansa', 'Kaiserin des Nordens', 'Moje Hammarberg', 'Pink Grootendorst', 'Rugeaux du Japon'. With 'Max Graf', leaves remain green until the first days of winter.

The examined cultivars were characterized by high tolerance to diseases, and the appearance of evident symptoms of blackspot and mildew was not observed. In the research conducted in the Research Insti- tute of Pomology and Floriculture, the highest level of resistance to Diplocarpon rosae among the examined roses was observed in Rosa rugosa hybrids: 'Hansa' and 'Moje Hammarberg', whereas 'Pink Grootendorst' and 'Max Graf' were moderately resistant, showing a small amount of infection (Wiśniew ska-Grzeszkiewicz et al. 1999).

The observations made indicate that the above cultivars derived from the Rugosa can be successfully cultivated in the climatic conditions of Poland for many years. Frost resistance is one of the most important factors determining the success of cultivation and decorativeness of shrubs in the season, and cultivars derived from the Rugosa are recommended to be planted in the cool climate of Canada and Scandinavia (C a r l s o n, 1993; Ogilvie and Arnold, 1995). In terms of frost resistance, in comparison with numerous other varieties of ground roses (C zekalski et al. 1990) also observed in the Botanical Garden, both historical cultivars (M o n d e r, 2004b, 2007a, 2007b, 2011) and other cultivars derived from the Rugosa (M o n d e r, 2004a, 2008a, 2008b, 2010) scored favourably (Table 2). Fruit (P o p e k, 2002) and flower pollen ( $\mathrm{S} \mathrm{z} \mathrm{k} \mathrm{l} \mathrm{a} \mathrm{-}$ n o w s k a, 1992; P o p e k, 2002) are food, and dense, thorny shrubs are a shelter for small fauna living in cities. Due to their small requirements in terms of cultivation and tolerance to diseases they deserve wider use, both as amateur varieties and for green areas.

Table 1.

The historical cultivars of Rugosa (Rosa rugosa Thunb.) hybrids belonging to the Collection of Rose Cultivars of the PAS Botanical Garden in Powsin

\begin{tabular}{|c|c|c|c|}
\hline Cultivar & Origin & $\begin{array}{l}\text { Year of planting } \\
\text { in collection }\end{array}$ & $\begin{array}{l}\text { Number of } \\
\text { shrubs }\end{array}$ \\
\hline 'Agnes' & $\begin{array}{l}\text { R. rugosa Thunb. x R. foetida Herrm. 'Persian Yellow', } \\
\text { W. Saunders before 1884, introd. } 1922\end{array}$ & 2002 & 3 \\
\hline 'Belle Poitevine' & $\begin{array}{l}\text { seedling of } R \text {. rugosa var. regeliana Wittm., François-Georges } \\
\text { Bruant } 1894\end{array}$ & 2002 & 5 \\
\hline 'Blanc Double de Coubert' & seedling of $R$. rugosa 'Alba' Rehder, C.P.M. Cochet-Cochet 1892 & 2005 & 8 \\
\hline 'F.J. Grootendorst' & $\begin{array}{l}\text { R. rugosa var. rubra Rehder x 'Mme Norbert Levavasseur', } \\
\text { de Goey } 1918\end{array}$ & 1998 & 4 \\
\hline 'Frau Dagmar Hastrup' & R. rugosa Thunb., unknown, K. J. Hastrup 1914 & 1999 & 6 \\
\hline 'Hansa' & unknown, Schaum van Tol 1905 & 1998 & 8 \\
\hline 'Kaiserin des Nordens' & $\begin{array}{l}R \text {. rugosa Thunb. x } R \text {. davurica Pall., } \\
\text { Eduard August von Regel } 1879\end{array}$ & 2006 & 3 \\
\hline 'Max Graf' & R. rugosa Thunb. x R. wichuraiana Crčp., J. H. Bowditch 1918 & 1999 & 10 \\
\hline 'Moje Hammarberg' & unknown, Hammarberg 1931 & 1999 & 5 \\
\hline 'Mrs Anthony Waterer' & R. rugosa Thunb. X 'General Jacqueminot', J. Waterer 1898 & 2001 & 2 \\
\hline 'Pink Grootendorst' & sport of 'F.J. Grootendorst', F.J. Grootendorst 1923 & 2003 & 4 \\
\hline 'Rugeaux du Japon' & unknown, 19th century & 2001 & 10 \\
\hline
\end{tabular}


Table 2.

Frost damage in the historical cultivars derived from the Rugosa (Rosa rugosa Thunb.) in the PAS Botanical Garden in Powsin according to the scale of frost damage to deciduous plants by Łukasiewicz (1992)

\begin{tabular}{|c|c|c|c|c|c|c|c|c|c|c|c|c|}
\hline \multirow[b]{2}{*}{ Cultivar } & \multicolumn{12}{|c|}{ Year } \\
\hline & छे & ఠ్ & ๙ิ & ڤి & ఫ્ત & ڤి & ๕ั & ڤ્ণ & ஓें & ஓे & $\stackrel{\circ}{\circ}$ & $\vec{\nabla}$ \\
\hline 'Agnes' & - & - & - & 4 & 4 & 4 & 0 & 0 & 0 & 0 & 6 & 4 \\
\hline 'Belle Poitevine' & - & - & - & 0 & 0 & 0 & 0 & 0 & 0 & 0 & 0 & 0 \\
\hline $\begin{array}{l}\text { 'Blanc Double } \\
\text { de Coubert' }\end{array}$ & - & - & - & - & - & - & 0 & 0 & 0 & 0 & 0 & 0 \\
\hline 'F.J. Grootendorst' & - & - & 0 & 4 & 0 & 0 & 1 & 0 & 0 & 0 & 4 & 6 \\
\hline 'Frau Dagmar Hastrup' & 0 & 0 & 0 & 0 & 4 & 0 & 0 & 0 & 0 & 0 & 0 & 0 \\
\hline 'Hansa' & 0 & 0 & 0 & 0 & 0 & 0 & 0 & 0 & 0 & 0 & 0 & 0 \\
\hline 'Kaiserin des Nordens' & - & - & - & - & - & - & - & 0 & 0 & 0 & 0 & 0 \\
\hline 'Max Graf' & 0 & 4 & 4 & 6 & 0 & 4 & 6 & 0 & 0 & 4 & 6 & 4 \\
\hline 'Moje Hammarberg' & 0 & 0 & 0 & 0 & 0 & 0 & 0 & 0 & 0 & 0 & 0 & 0 \\
\hline 'Mrs Anthony Waterer' & - & - & - & 4 & 4 & 4 & 0 & 0 & 0 & 0 & 4 & 0 \\
\hline 'Pink Grootendorst' & - & - & - & - & 4 & 4 & 1 & 0 & 0 & 0 & 4 & 1 \\
\hline 'Rugeaux du Japon' & - & - & - & 0 & 0 & 0 & 0 & 0 & 0 & 0 & 0 & 0 \\
\hline
\end{tabular}

Table 3.

Evaluation of growth and flowering of the historical cultivars derived from the Rugosa (Rosa rugosa Thunb.) in the PAS Botanical Garden in Powsin

\begin{tabular}{|c|c|c|c|c|c|c|c|c|c|c|}
\hline \multirow{2}{*}{ Cultivar } & \multicolumn{5}{|c|}{ Average date of } & \multicolumn{5}{|c|}{$\begin{array}{c}\text { Shrub height }[\mathrm{cm}] \text { at the time of flowering } \\
\text { / at the end of October }\end{array}$} \\
\hline & $\begin{array}{c}\text { bud } \\
\text { break }\end{array}$ & $\begin{array}{c}\text { leaf } \\
\text { develop- } \\
\text { ment }\end{array}$ & $\begin{array}{l}\text { initial } \\
\text { flowering }\end{array}$ & $\begin{array}{l}\text { full } \\
\text { flowering }\end{array}$ & $\begin{array}{c}\text { final } \\
\text { flowering }\end{array}$ & 2000 & 2003 & 2006 & 2009 & 2011 \\
\hline 'Agnes' & early & early & $20-25.05$ & $25.05-25.06$ & $20.06-1.07$ & - & $150 / 170$ & $150 / 170$ & $150 / 170$ & $150 / 170$ \\
\hline 'Belle Poitevine' & early & semi-early & $15.05-22.06$ & $18.05-13.06$ & $15.06-1.07$ & 80 & $100 / 150$ & 150 & 150 & 150 \\
\hline $\begin{array}{l}\text { 'Blanc Double de } \\
\text { Coubert' }\end{array}$ & early & semi-early & $20-25.05$ & $25.05-25.06$ & $20.06-1.07$ & - & - & $50 / 60$ & $50 / 90$ & $90 / 110$ \\
\hline 'F.J. Grootendorst' & early & early & $1-5.06$ & $5-20.06$ & - & - & $50 / 90$ & $150 / 170$ & $140 / 180$ & $140 / 170$ \\
\hline $\begin{array}{l}\text { 'Frau Dagmar } \\
\text { Hastrup' }\end{array}$ & semi-early & semi-early & $15.05-17.05$ & $18.05-15.06$ & $15-20.06$ & $30 / 40$ & $50 / 60$ & 60 & 60 & 60 \\
\hline 'Hansa' & early & early & $20-25.05$ & $25.05-25.06$ & $20.06-1.07$ & 80 & $100 / 150$ & 170 & 180 & 180 \\
\hline $\begin{array}{l}\text { 'Kaiserin des } \\
\text { Nordens' }\end{array}$ & early & semi-early & $18-20.05$ & $22.05-12.06$ & $14-16.06$ & - & - & - & $120 / 150$ & 150 \\
\hline 'Max Graf' & semi-early & semi-early & $25 .-28.05$ & $25.05-15.06$ & $17-20.06$ & $50 / 70$ & $50 / 70$ & $50 / 70$ & $50 / 70$ & $50 / 70$ \\
\hline 'Moje Hammarberg' & early & semi-early & $12-15.05$ & $15.05-17.06$ & $17-20.06$ & $120 / 120$ & $120 / 140$ & 140 & 140 & 140 \\
\hline $\begin{array}{l}\text { 'Mrs Anthony } \\
\text { Waterer' }\end{array}$ & early & semi-early & $26.05-1.06$ & $26.05-25.06$ & $20.06-1.07$ & - & $150 / 200$ & $150 / 200$ & $150 / 230$ & $150 / 230$ \\
\hline 'Pink Grootendorst' & early & early & $1-5.06$ & $5-20.06$ & - & - & $50 / 90$ & $150 / 170$ & $140 / 180$ & $140 / 170$ \\
\hline 'Rugeaux du Japon' & early & early & $22-25.05$ & $25.05-25.06$ & $20-25.06$ & - & $130 / 150$ & $150 / 170$ & 170 & 170 \\
\hline
\end{tabular}




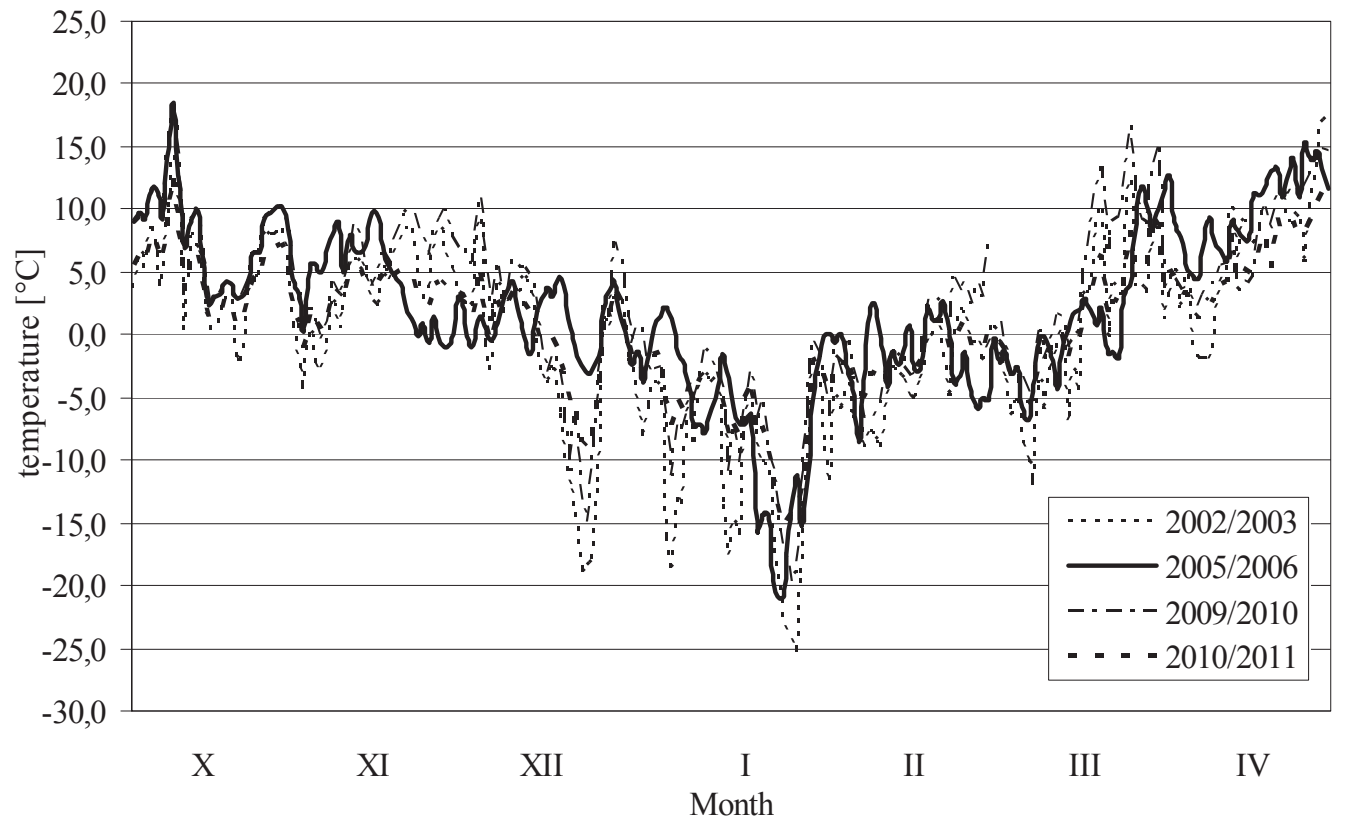

Fig. 1. Average twenty-four air temperatures [ $\left.{ }^{\circ} \mathrm{C}\right]$ from October to April in the following autumn-winter seasons: 2002/2003, 2005/2006, 2009/2010, 2010/2011, in the PAS Botanical Garden in Powsin.

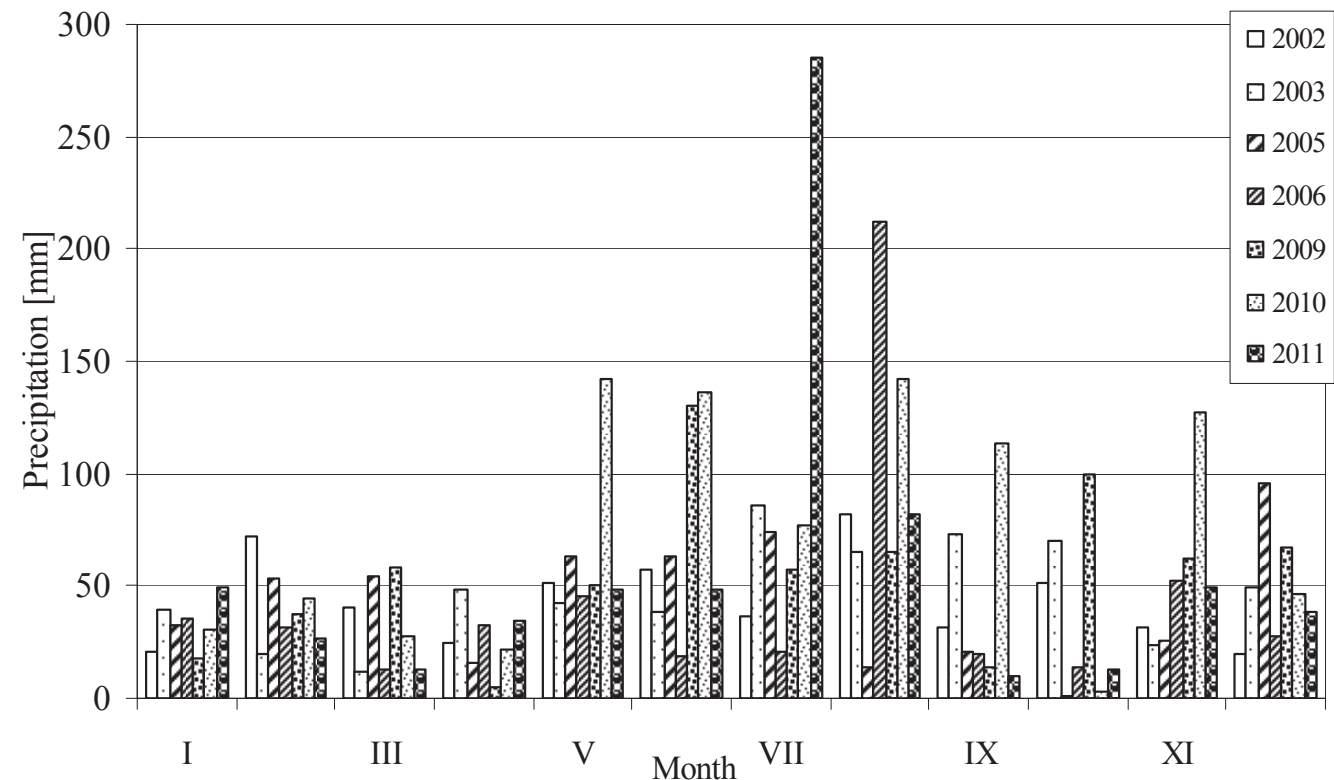

Fig. 2. Total monthly precipitation [mm] in the following years: 2002-2003, 2005-2006, 2009-2010 and 2011, in the PAS Botanical Garden in Powsin.

\section{CONCLUSIONS}

1. The examined historical cultivars derived from the Rugosa are characterized by very high tolerance to unfavourable winter conditions in central Poland. The highest level of frost resistance is shown by: 'Belle Poitevine', 'Blanc Double de Coubert', 'Frau Dagmar Hastrup', 'Hansa', 'Kaiserin des Nordens', 'Moje Hammarberg', 'Rugeaux du Japan'. Little frost damage occurs in 'Agnes', 'F.J.
Grootendorst', 'Max Graf', 'Mrs Anthony Waterer', 'Pink Grootendorst'.

2. Flowering in Rugosas begins early. In the second decade of May, flowers appear in 'Belle Poitevine', 'Frau Dagmar Hastrup', and 'Moje Hammarberg'. The last to flower, in the first decade of June, are 'F.J. Grootendorst' and 'Pink Grootendorst'.

3. High tolerance to diseases, little tending needs and favourable decorative features throughout the growing season make the examined historical 
cultivars derived from the Rugosa useful for a wide application in parks, in urbanized areas and in historical garden layouts, some as ground cover and soil-protective forms.

\section{REFERENCES}

Anderson E., 1932. Rosa rugosa and its hybrids. Arnold Arboretum Harward University. Bull. of Popular Inform.. Series 3, VI., 24 June: 29-35.

B u g a ł a W., 2000. Drzewa i krzewy. Państwowe Wydawnictwo Rolnicze i Leśne. Warszawa. (in Polish)

Carls on U., 1993. Breeding winter-hardy woody ornamentals for the Swedish climate. Plantsman. 15(3): 185-188.

Czekalski M., Oszkinis K., Żyła S., 1990. Uszkodzenia mrozowe róż powstałe podczas zimy 1986/1987 / Frost damage to roses during the winter of 1986/1987. Ogrodnictwo 1-3: 44-45. (in Polish)

Heinze W., Schreiber D., 1984. Eine neue Kartierung der Winterhärte Zonen für Gehölze in Mitteleuropa. Mitt. Dtsch. Dendrol. Ges. 75: 11-56. (in German)

Henschke M., 2007. Wpływ wiosennego cięcia pędów i ściółkowania gleby na wzrost i kwitnienie okrywowych odmian róż. Praca doktorska pod kierunkiem prof. dr hab. Marka Jerzego, w Katedrze Roślin Ozdobnych Akademii Rolniczej im. Augusta Cieszkowskiego w Poznaniu. (in Polish)

Jerzy M., Żyła S., Czekalski W., 1992. Róże. Państwowe Wydawnictwo Rolnicze i Leśne. Warszawa. (in Polish)

K rüs s man n G., 1974. Rosen Rosen Rosen. Unser Wissen über die Rosen. Verlag Paul Parey. Berlin und Hamburg. (in German)

Łukasiewicz A., 1992. Zahamowanie rozwoju pąków u niektórych drzew iglastych po surowej zimie 1986/1987 i wynikająca stąd potrzeba uzupełnienia skali przemrożeń u drzew i krzewów. Bull. Bot. Gar., Museums Coll. 1, 53-57. (in Polish)

Monder M. J., 2001. Rosa rugosa Thunb. i jej odmiany - cennymi różami parkowymi w kolekcji Ogrodu Botanicznego CZRB PAN w Warszawie. Bull. Bot. Gar., Museums Coll. 10: 47-56. (in Polish)

Monder M.J., 2004a. Observations of frost resistance of cover roses in the roses collection in the Botanical Garden of Polish Academy of the Sciences in Warsaw after frosty winter 2002/2003. Bull. Bot. Gar. Museums Coll. 13: 187-197.

Monder M.J., 2004b. Observations of overwintering of historical roses in roses collection of Botanical Garden of Polish Academy of Sciences in Warsaw after frosty winter 2002/2003. Bull. Bot. Gar. Museums Coll. 13: 197-207.

Monder M.J., 2007a. Charakterystyka wzrostu i wartości dekoracyjnej wybranych odmian parkowych róż historycznych. XI Nursery Conf. Problemy i perspektywy produkcji szkółkarskiej roślin ozdobnych, Skierniewice,
Poland, Wydawnictwo Inst. Sadow. Kwiac.: 31-40. (in Polish)

Monder M.J., 2007b. Zasoby genowe i ocena wybranych odmian róż historycznych w kolekcji Ogrodu Botanicznego CZRB PAN. / Genetic resources and evaluation of selected historical roses belonging to the Collection of Botanical Garden of Polish Academy of Sciences in Warsaw. Zesz. Probl. Post. Nauk Roln. 517, part II: 487-494. (in Polish)

Monder M.J., 2008a. Ocena wzrostu i kwitnienia 10 wybranych odmian róż z grupy okrywowych. / Evaluation of growth and flowering of ten ground cover cultivars of roses. Zesz. Probl. Post. Nauk Roln. 525: 261-269. (in Polish)

Monder M. J., 2008b. Odmiany róż angielskich w Kolekcji Odmian Uprawnych Róż Ogrodu Botanicznego CZRB PAN w Warszawie. Bull. Bot. Gar. Museums Coll. 17: 81-89. (in Polish)

Monder M.J., 2009. Różnorodność i charakterystyka wybranych odmian pochodzących od róży pomarszczonej (Rosa rugosa Thunb.). XIII Konferencja Szkółkarska „Produkcja drzew i krzewów ozdobnych oraz ich wykorzystanie w terenach zurbanizowanych". Materiały Konferencyjne: 21-28. (in Polish)

Monder M. J., 2010. Ocena stanu krzewów 368 odmian róż po sezonie zimowym 2009/2010 w Ogrodzie Botanicznym PAN w Warszawie. / Evaluation of the condition of shrubs of 374 rose cultivars in the Rose Collection of the PAS Botanical Garden in Warsaw after the 2009/2010 winter season. Rocznik PTD, LVIII: 39-52. (in Polish)

Monder M., 2011. Evaluation of growth and flowering of cultivars derived from the Pimpinellifolia (Rosa pimpinellifolia L.) growing in the Collection of Rose Cultivars in the Botanical Garden of the Polish Academy of Sciences. J. Fruit Ornam. Plant Res. 19(1): 195-207.

Monder M.J., 2012. Evaluation of growth and flowering of cultivars derived from the Rugosa (Rosa rugosa Thunb.) growing in the National Collection of Rose Cultivars in the Polish Academy of Sciences Botanical Garden in Powsin. Part II. The modern cultivars. Acta Agrobot. (in press).

Ogilvie I.S., Arnold N.P., 1995. The "Explorer" series of roses from Ottawa and L'Assomption. HortScience. 30(1): 2, 175.

Popek R., 1996. Biosystematyczne studia nad rodzajem Rosa L. w Polsce i krajach ościennych. Wydawnictwa Naukowe WSP, Kraków. 146. (in Polish)

Popek R., 2002. Róże dziko rosnące Polski. Wydawnictwo Plantpress. Kraków. (in Polish)

Sikora D., 2006. Restauracja zabytkowych parków i ogrodów, gospodarka drzewostanem parkowym. Przyroda i miasto. Tom VIII. Wydawnictwo SGGW: 231-235. (in Polish)

Szk la nowska K., 1992. Wydajność pyłkowa niektórych ozdobnych drzew i krzewów z rodziny różowatych (Rosaceae). / Pollen yield of some ornamental trees and 
shrubs from the Rosaceae family. Pszczelnicze Zeszyty Naukowe - J. Apic. Sci. 36: 65-73. (in Polish)

Wiśniewska-Grzeszkiewicz H., Wojdyła A., Rejman S., 1999. Ocena podatności róż na czarną plamistość liści (Diplocarpon rosae Wolf.). Zesz. Nauk. ISiK. w-Skierniewicach. 6: 189-199. (in Polish)

Zaraś E., Lat ocha P., 2000. Okrywowe krzewy liściaste i iglaste jako elementy korzystnie wpływające na środowisko miejskie / Ground cover broad-leaved and coniferous shrubs as elements which positively affect the urban environment. Przyroda i miasto / Nature and the city, III: 187-201. (in Polish)

http://www.iop.krakow.pl/ias/Gatunek.aspx?spID=147

\section{Wzrost i kwitnienie odmian pochodzących od róży pomarszczonej (Rosa rugosa Thunb.) w Kolekcji Narodowej Odmian Uprawnych Róż PAN w Ogrodzie Botanicznym CZRB w Powsinie.}

\section{Część I. Odmiany historyczne}

\section{Streszczenie}

W latach 2000-2011 prowadzono obserwacje krzewów 29 odmian pochodzących od róży pomarszczonej (R. rugosa Thunb.) gromadzonych w Kolekcji Odmian Uprawnych Róż PAN w Ogrodzie Botanicznym CZRB w Powsinie. W części pierwszej przedstawiono wyniki dla 12 odmian historycznych ('Agnes', 'Belle Poitevine', 'Blanc Double de Coubert', 'F.J. Grootendorst', 'Frau Dagmar Hastrup', 'Hansa', 'Kaiserin des Nordens', 'Max Graf', 'Moje Hammarberg',
'Mrs Anthony Waterer', 'Pink Grootendorst', 'Rugeaux du Japon'). Corocznie u krzewów notowano uszkodzenia spowodowane przez mróz; zapisywano datę pękania pąków i rozwoju liści na wiosnę; obserwowano regenerację uszkodzonych w czasie zimy krzewów; notowano datę początku, pełni i końca kwitnienia; obecność objawów porażenia przez choroby; oraz uwagi dotyczące konieczności wykonywania cięcia wiosennego i po kwitnieniu.

Sezony zimowe 2002/2003, 2005/2006, 2009/2010, 2010/2011 należały do niekorzystnych dla róż. Odmiany charakteryzowały się zróżnicowaniem pod względem badanych cech. Do zalet większości odmian należy wysoka mrozoodporność, wczesne kwitnienie, małe wymagania pod względem cięcia, dobra zdrowotność. Bardzo wysoką odpornością na mróz charakteryzują się: 'Belle Poitevine', 'Blanc Double de Coubert', 'Frau Dagmar Hastrup', 'Hansa', 'Kaiserin des Nordens', 'Moje Hammarberg', 'Rugeaux du Japon'. Odmiany nieznacznie uszkadzane przez mróz to: 'Agnes', 'F.J. Grootendorst', 'Max Graf', 'Mrs Anthony Waterer', 'Pink Grootendorst'. Najwcześniej, w połowie maja, zakwitają 'Belle Poitevine', 'Frau Dagmar Hastrup', 'Kaiserin des Nordes', 'Moje Hammarberg'. Odmiany pochodzące od róży pomarszczonej powinny znaleźć szersze zastosowanie jako róże parkowe ('Agnes', 'Belle Poitevine', 'F.J. Grootendorst', 'Frau Dagmar Hastrup', 'Mrs Anthony Waterer', 'Pink Grootendorst', 'Rugeaux du Japon') oraz okrywowe i glebochronne ('Blanc Double de Coubert', 'Hansa', 'Kaiserin des Nordens', 'Max Graf', 'Moje Hammarberg') na terenach zieleni miejskiej i przy obiektach zabytkowych. 